UDC 009.4+655.28.022.2

\title{
OPTICAL QUALITY OF THE IMAGE AND METHODS OF ITS DETERMINATION
}

\author{
B. Havrysh ${ }^{1}$, O. Tymchenko ${ }^{1,2}$, M. Logoida ${ }^{3}$, U. Partyka ${ }^{4}$, M. Polischuk ${ }^{5}$, \\ Y. Slyusarchuk ${ }^{3}$, O. Slyusarchuk ${ }^{3}$ \\ ${ }^{1}$ Ukrainian Academy of Printing \\ 19, Pid Holoskom St., Lviv, 79020, Ukraine \\ ${ }^{2}$ University of Warmia and Mazury \\ 2, M. Oczapowskiego St., Olsztyn, 10-719, Poland \\ ${ }^{3}$ National University «Lviv Polytechnic» \\ 12, S. Bandera St., Lviv, 79013, Ukraine \\ ${ }^{4}$ Lviv Institute of Nursing and Laboratory Medicine named after Andrew Krupynskiy, \\ 70, P. Doroshenko St., Lviv, 79013, Ukraine \\ ${ }^{5}$ Lviv Higher Vocational School of Computer Technologies and Construction \\ 23, A. Linkoln St., Lviv, 79068, Ukraine
}

The main objective of the assessment of the production process is obtaining objective information on the functioning of equipment and technology for the identification of intensification reserves of production to increase its efficiency and quality, increase production, increase productivity, reduce all kinds of material and labour costs. Quality is a set of characteristics of the object concerning its ability to meet established and anticipated needs. The article deals with the evaluation criteria such as quality image resolution, i.e. the ability to separately observe the image of two very close objects.

Keywords: discriminability, light energy, aperture, optical system, image quality.

\section{INTRODUCTION}

The main objective of the evaluation of production processes is obtaining objective information on the functioning of the equipment and identification of technology reserves in order to intensify production, enhance its efficiency and quality, increase production volumes, increase labour productivity, reduce all kinds of material and labour costs. Quality is a set of characteristics of the object associated with its ability to meet the established and anticipated needs [1]. Quality of technological processes is a set of properties of the technological process that determine its suitability for a given process. The number of factors affecting the quality indicators is rather large and requires an in-depth study. The most common indicator to evaluate the image quality of an optical system is the resolution, i.e. the ability to separately observe the images of two objects located very close to each other [2]. 


\section{DETERMINATION OF THE RESOLUTION OF OPTICAL SYSTEMS}

All optical devices, regardless of their specifics and purpose, always have one common physical property called resolution. This physical property is crucial for any and all optical and measurement optical devices [3].

Resolution of optical devices is a value that describes the ability to distinguish the smallest details of some observed or measured objects. The resolution limit is a minimum distance between adjacent parts (points) of an object when image details are no longer perceived as separate elements of the object, but merge together. The smaller is this distance, the higher is the resolution of the device respectively.

Resolution of devices goes down in the presence of aberrations (deviations of the light beam from the set direction) and various manufacturing measurement errors of optical systems, which increases the size of the diffraction spots. Thus, the lower is the value of the diffraction spots, the higher is the optical resolution. This is an important indicator [4].

The resolution of any optical device is measured by its technical functions, which reflects all the factors that affect the quality of the image made with this device. Such factors, apparently, include first of all, aberration and diffraction - diffracting interferences with light waves and, consequently, their deviation from the straight linear direction [5].

Suppose that the system builds a dotted image with a homocentric cluster that has its centre at point $\mathrm{A}^{\prime}$ and comes from the system filling a small aperture angle $2 \sigma^{\prime}$.

Due to the diffraction even a perfect system reproduces a point as a scattered spot of final size, and the light distribution around point $\mathrm{A}^{\prime}$ in the image plane is the result of interference [6].

Lightness of the image $\mathrm{E}^{\prime}$ at point $\mathrm{B}^{\prime}$ located outside on the axis at the distance $\mathrm{r}^{\prime}$ from the point $\mathrm{A}^{\prime}$ will be different from the lightness $E_{0}^{\prime}$ at the point $\mathrm{A}^{\prime}$.

Ratio $E^{\prime} / E_{0}^{\prime}$ is called the relative lightness at this point (1), (2):

$$
\frac{E^{\prime}}{E_{0}^{\prime}}=4\left[\frac{J_{1}\left(x_{1}\right)}{x_{1}}\right]^{2}
$$

or

$$
E^{\prime}=4 E_{0}^{\prime}\left[\frac{J_{1}\left(x_{1}\right)}{x_{1}}\right]^{2}
$$

where $x_{1} \approx 2 \pi n^{\prime} \sigma^{\prime} r^{\prime} / \lambda, J_{1}$ is a Bessel function of the first kind.

Central maximum corresponds to the bright spot, where approximately $84 \%$ of energy is concentrated, and peripheral maximums correspond to light rings.

The radius of the central spot of diffraction image of the illuminated point for round aperture equals (3):

$$
r^{\prime}=\frac{\lambda x_{1}}{\left(2 \pi n^{\prime} \sin \sigma^{\prime}\right)} \approx \frac{\lambda x_{1}}{\left(2 \pi n^{\prime} \sigma^{\prime}\right)},
$$

where $x_{1}$ is the distance from the centre of the diffraction spot in dimensionless units, $\lambda$ is the wavelength.

The angle in the space of objects that corresponds to the central part of the diffraction spot in the plane of image, equals to: 


$$
\psi=\frac{\lambda x_{1}}{\pi D}
$$

where: $D$ is a diameter of the input pupil, $\mathrm{mm}$.

If two illuminated points are located close to each other, their diffraction images can overlap each other, and the illuminations in the overlapping places add up. For the separate perception of two points, it is necessary that the difference between maximum and minimum illuminations in total diffraction picture reaches a certain value (Fig. 1). It is assumed that at the value $E^{\prime} / E_{0}{ }^{\prime} \leq 0.8$ the system can distinguish between the two points [7].

Substituting in (4) the radius of the first dark ring $x_{1}=3.8317$, we have (5):

where $\mathrm{D}$ is a diameter of the input pupil, $\mathrm{mm}$.

$$
\psi=1,22 \lambda / D
$$

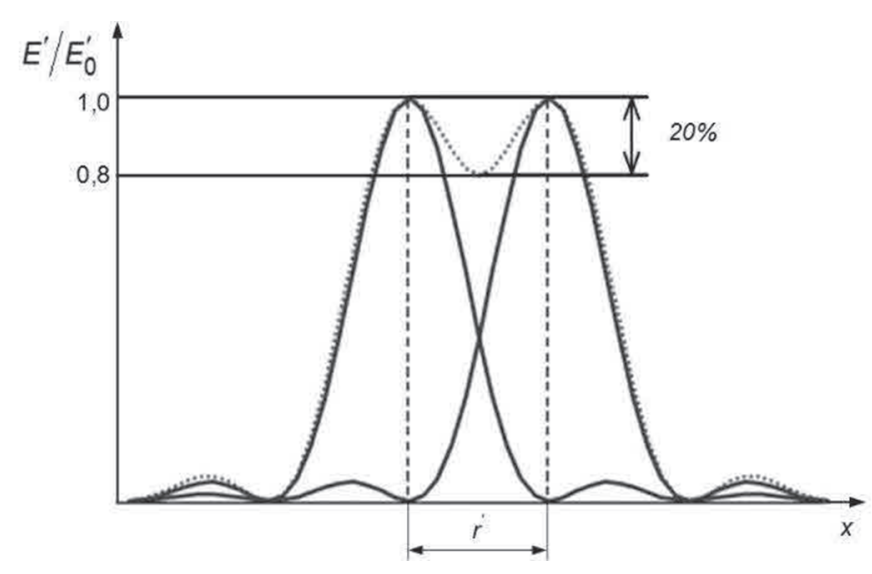

Fig. 1. Lightness distribution in the diffraction image of two illuminated points

\section{DETERMINATION OF OPTICAL QUALITY OF THE IMAGE}

Quality of the optical image is a degree of correspondence to geometric, photometric and spectral characteristics of the image and the object. The image should be similar to the object, not only in terms of contour, but also in every its point: due to aberrations and diffractions an obtained image is blurred and fine structure is rendered incorrectly [8]. It should be taken into account that:

1. given a small field of view, it is sufficient to look at an image from the axial point that has to be ideal;

2. given an art reproduction, it shall be looked at according to geometric and spectral characteristics and necessary colour transmission coefficient;

3. optical systems used in a communication channel should transmit and register the maximum amount of information coming from the object.

Quality parameters in evaluation of image quality include contrast of image components and their relative position within the field; possibility of registration of image elements by different receivers with minimal distortion; phase transfer function that defines 
quality correspondence of the geometric position of the image elements to the object; dispersion function that allows to mathematically describe the distribution of illumination in the image (dispersion function of a point is calculated as the square modulus of the Fourier transform of pupil function that includes the pupil contour as detection area and the aberration of the wave for a given point of the field as an argument; dispersion function of a line is the intensity distribution in the image of an infinitely long line in direction $Y$-meridional dispersion function of a line or $X$-sagittal dispersion function of a line) $a_{0}$.

Resolution of objective lenses of telescopic systems is expressed as an angular measure, resolution of camera lenses - as lines (strokes) per $1 \mathrm{~mm}$, and resolution of lenses of microscopes - in a linear way (in micrometers). However, in the case of a large residual aberration the resolution of the system is not an exhaustive characteristic of the image quality [9].

Optical systems with the same resolutions but different residual aberrations do not have the same image quality [10]. A real system builds an image that is not different from the ideal one, if residual wave aberration does not exceed a quarter of the wave length $N \leq \lambda / 4$. However, this criterion does not take into account rendering of contrast by a system. Taking into account the contrast, evaluation of image quality can be made on the basis of Strehl criteria. For this purpose, it is necessary to define the illumination $\mathrm{E}^{\prime}$ made by a real system in the centre of the scattering circle, and to compare it with the illumination of the ideal system $E_{0}$. The ratio of illuminations $E^{\prime} / E_{0}{ }^{\prime}$ is called the determining brightness or the Strehl number. Image quality deteriorates considerably, if the wave aberration exceeds the Rayleigh $\operatorname{limit}(N \leq \lambda / 4)$ or, what is almost the same, when aberration has a value for which Strehl number becomes less than 0.8. Rayleigh and Strehl ratios define the limits for wave aberration values at which the image is perfect.

When designing new optical systems, especially photographic ones, it is necessary to carry out a comprehensive study of their quality and to obtain a respective image quality criterion. This is achieved with the method of modulation transfer function [11].

An illuminated point is represented by an optical system as a final-dimension spot. The degree of mismatch of distribution of image illumination with brightness distribution of the object can be a measure of image quality of a system. In the method of modulation transfer function cosine measure is applicable as a test-object (object).

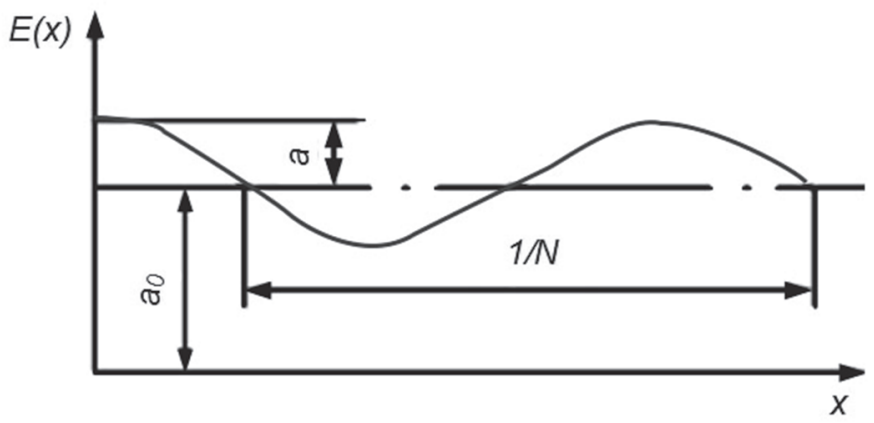

Fig. 2. Cosine distribution of illumination 
The distribution of light energy, represented graphically on Figure 2, is characterized by the ratio (6):

$$
k^{\prime}=\frac{\left(E_{\max }^{\prime}-E_{\text {min }}^{\prime}\right)}{\left(E_{\max }^{\prime}+E_{\min }^{\prime}\right)},
$$

where $E_{\max }$ and $E_{\min }$ are maximum and minimum illuminations (or brightness) of the object.

\section{QUALITY CONTROL OF THE POLYGRAPHIC IMAGE}

The following parameters can be used in digital polygraphic production for quality control of the output image at the stages of exposure and development: parameters of energy transformation of information signal, space and frequency parameters, and colour parameters. Each group of parameters has its quality criteria and factors that influence them [12]. The characteristics of a photoreceptor (such as energy irradiance, exposure, and sensitivity) and contrast of electrostatic latent image define optical density of an image, background, and raster structure. The line width resolution, scan lineature and number of semitones are affected by the diameter of an energy spot in the plane of the photoreceptor, energy irradiance distribution within the spot, spatial frequency of raster scanning, raster halftone structure and size of particles of the toner. Colour parameters depend on the properties of a colour toner, thickness balance of colour toners during the image synthesis, structure homogeneity of colour elements and colour characteristics of the image of raster structure [13].

For digital imaging equipment it is important to control the reproduction of stroke details. Tints (solid areas) are characterised by microraster structure formed in the process of frame-by-frame image sweep. Modern digital printing machines have spatial frequency of such grid not below $600 \mathrm{dpi}$ or $24 \mathrm{~mm}^{1}$.

Assessment of indicators shall be straightforward and clear for a wide audience of specialists, i.e. test strip shall contain objects that can be measured with instruments available to publishing houses (magnifying glass, spectrophotometer). On the basis of the mentioned requirements for evaluation of the quality of digital imaging, the following properties indicators are suggested for quality control according to the comprehensive method: optical density of background and image, printing uniformity, tone reproduction, colour gamut of printing and reproduction of living colours, printing resolution, imaging layer adhesion and adhesion of toner to the paper.

Taking into account the general quality control requirements and mentioned quality control indicators, the properties of digital imaging of polygraphic products can be shown as a graphic scheme (Fig. 3).

Photographic properties indicators characterising reproduction of image details include printing heterogeneity, tonal accuracy and reproduction of fine details. Printing heterogeneity is usually associated with uniformity of tints (uniformity of print) and the presence of extraneous characters, which in electrophotographic printing process is defined based on the value of optical background density (optical density of the background). Tonal accuracy is defined on the basis of the nature of semitones reproduction (image tones) and the image optical density level [14]. 


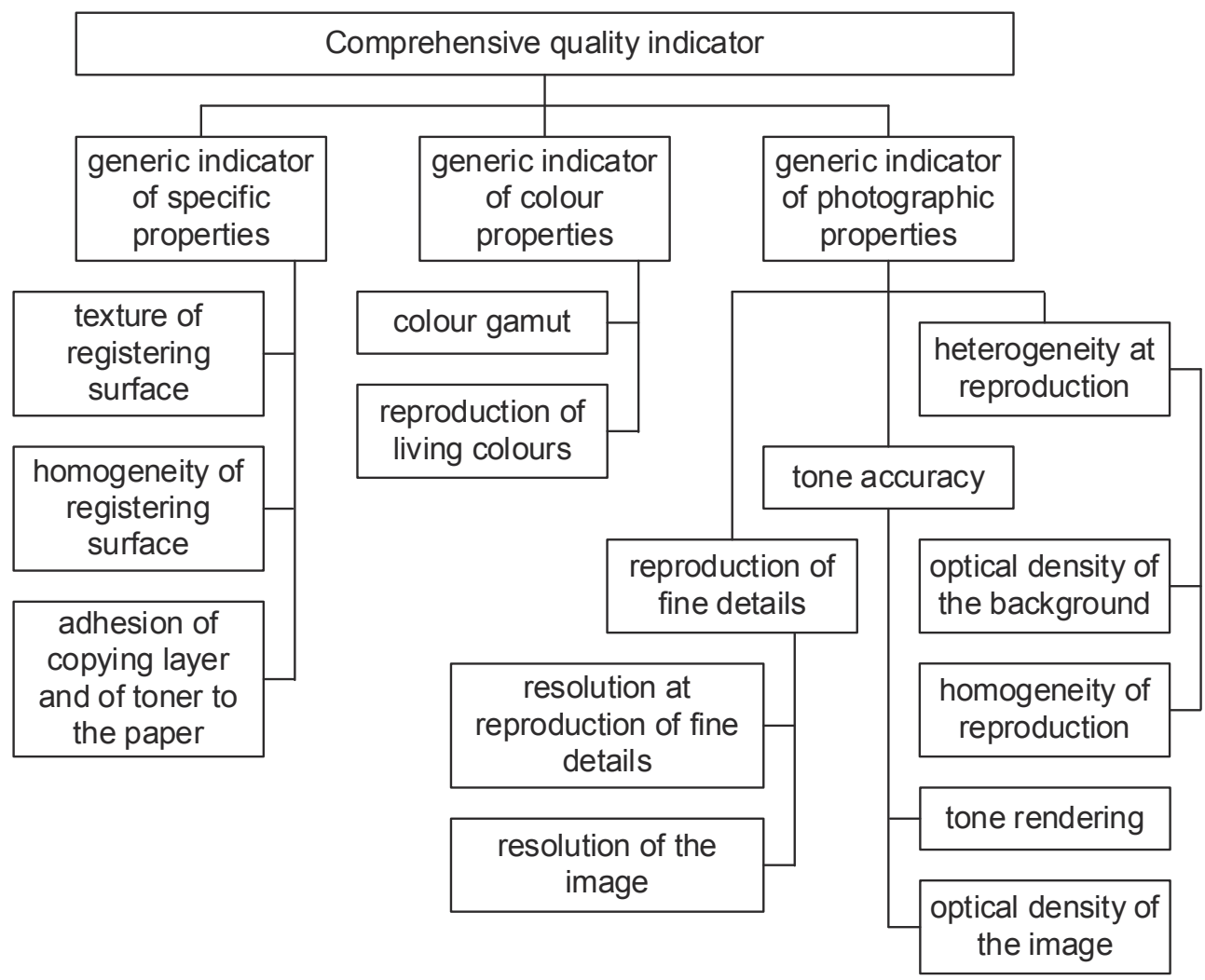

Fig.3. Hierarchical structure of indicators of digital reproduction quality of printed products

It is recommended to control the reproduction of fine details based on the resolution value (ability to reproduce fine details) and reproduction resolution (controlled by reproduction of concentric circles) of the system. These concepts are very close, but to control electrographic method of reproduction that has specific image recording method, not only reproduction of separate strokes under different angles is important, but also reproduction of stroke elements (such as circles), on which image raster structure is imposed due to the stage of exposure.

Image contrast measure (7) [14]:

$$
k^{\prime}=\frac{\left(E_{\text {max }}^{\prime}-E_{\text {min }}^{\prime}\right)}{\left(E_{\text {max }}^{\prime}+E_{\text {min }}^{\prime}\right)}=k|F(N)| \text {. }
$$

The modulus of the function $F(N)$ characterises the image contrast measure ratio to the contract of the measure itself. This value dependent on spatial frequency $N$, is called the coefficient of modulation transfer of an optical system. The set of values of the coefficients of modulation transfer for different space frequencies is a function of modulation transfer of the system. The function $F(N)$ is called complex modulation transfer function or optical transfer function. A function that characterises phase shift in the image of cosine measure, is called the phase transfer function [15]. 
The main error introduced in the process of rasterization is coused by nonlinearity [9].

Important options in scanning process are nonlinear coefficient in line scan and scanning trajectory.

Nonlinear coefficient in line scan characterizes a change degree of a light spot moving speed align of raster line and determines by the formula (8):

$$
K_{v}=\frac{\dot{x}(\varphi)}{\dot{x}(0)}-1
$$

where $\dot{x}(\varphi)=\frac{\partial x}{\partial \varphi} \times \frac{\partial \varphi}{\partial t}-$ line scan speed with the rotating angle of the deflector $\varphi ; \dot{x}(0)-$ line scan speed with $\varphi=0$.

Trajectory nonlinear coefficient of scanning characterizes a degree of a deviation of raster lines from straightforwardness in the photosensitive material's plane and determines by the formula (9):

$$
K_{t}=\frac{y(\varphi)}{y(0)}-1
$$

where $y(\varphi)$ - deviation of a scan line from 0x axis with the rotating angle of the deflector $\varphi ; y(0)$ - deviation of a scan line from $0 \mathrm{x}$ axis with the $\varphi=0$.

To eliminate the disadvantages of a image quality that are connected with nonlinearity of line scan in laser devices focusing $f \theta$-objectives are used. There is an artificially introduced appropriate distort for a nonlinearity linearization in $f \theta$-objectives. Such objectives provide a high precision of a line scan linearization law.

In such a way to ensure a quality recording in a laser image scanner an angle error in prism and pyramid mirror deflectors should be several angle seconds. It's possible to evaluate the impact on an image errors recording processes in other planes with installation inaccuracies angles considering of $\alpha_{1}, \alpha_{2}$ and $\alpha_{3}$ angles, that are deducted from appropriate axes $\mathrm{x}, \mathrm{y}, \mathrm{z}$, and also determine the total deviation error of a raster line from the set position by formula (10):

$$
\Delta y_{\Sigma}=f\left(\frac{\partial \Delta y_{B}}{\partial \theta} \Delta \theta+\frac{\partial \Delta y_{B}}{\alpha_{1}} \Delta \alpha_{1}+\frac{\partial \Delta y_{B}}{\alpha_{2}} \Delta \alpha_{2}+\frac{\partial \Delta y_{B}}{\alpha_{3}} \Delta \alpha_{3}\right),
$$

where $\Delta \alpha_{1}, \Delta \alpha_{2}, \Delta \alpha_{3}$ - errors in the corners towards Horta $S$, where $S$ - falling laser beam ort, connected with the deflector installation inaccuracy.

Consider the original scale for evaluating the resolution of raster output scanners. The developed test-object belongs to the scale of operational resolution controll of scanning output devices such as laser and inkjet printers, laser photo exhibit device system "Computer to plate", "Computer to press " and digital printing machines. The test-object includes scales for controlling scanning resolution of output devices through software control element synthesis which determins the actual visual resolution of the image resulting raster output scanning device. The scale consists of elements for determining the resolution in the areas of "fast", "slow" scan in angle of $45^{\circ}$ which gives the possibility of realistic evaluation of the actual resolution. Block diagram made for controlling a 
resolution (part of it is on the fig. 4 , where 1 - printing elements, 2 - unprinting), contains of 4 function groups, which consist of a thin ring and straight lines of equal thickness $(2.6458,5.2917,10.58,21.17,42.3,84.7 \mathrm{mkm})$.

The test-object consists of four functional groups, each containing 6 items with the resolution of 9600, 4800, 2400, 1200, 600, $300 \mathrm{dpi}$.
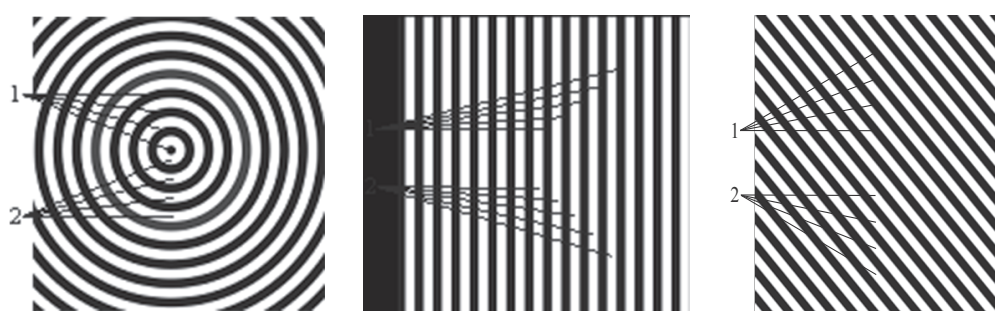

Fig.4. Main test-object elements for controlling the resolution $4800 \mathrm{dpi}$ (increasing 37000\%, 1 - stroke; 2 distance between strokes)

Using this scale for controlling the resolution is following:

The program file with the controlling scale outputs on the paper, photo-material or forming plate using the raster scanning and recording device and visually establish the value or a resolution in which the control elements are reproduced without distortion. Next for the found the correctly recreated fields of the resolution integrated optical density values measurements are carried out, which in the ideal case for $50 \%$ of dashed measure should be equal to 0.3. In deviation from this value setting scanning raster output device parameters are made.

\section{CONCLUSIONS}

According to the Rayleigh criterion residual spherical aberration of an optical system does not affect significantly the quality of an image, if the optical difference of motion of any pair of rays from the whole beam does not exceed $\lambda / 4$. In many modern optical systems the optical difference of motion is many times greater than the limit set by Rayleigh, which is explained by the fact that in many cases conditions of use of images allow large circles of dispersion (e.g. projecting an image on the screen or taking zoomed out photos).

Strehl ratio for the image quality evaluation takes into account computation of the light only in the centre of the dispersion circle and compares this lightness with the lightness of the centre of an ideal image given by the optical system with the same focal distance and relative aperture, but without spherical aberration.

The main advantage of the method of modulation transfer function is that it allows to consider relatively easy the quality of complex systems, such as photographic systems with electronic and optical converters of several components. Then modulation transfer function of the whole system equals to the product of MTF elements:

$$
F(N)=F_{1}(N) F_{2}(N) F_{3}(N) \ldots
$$

Combined use of Rayleigh and Strehl ratios allows determining the limits of wave aberration values at which the image can be considered as perfect. 
To evaluate the resolution of raster output scanners is needed to use the test-object, which allows to control effectively the resolution of output scanning devices and so the quality of received printing image.

\section{REFERENCES}

1. Peleshko D., Rak T., Izonin I. (2016). Image Superresolution via Divergence Matrix and Automatic Detection of Crossover. International Journal of Intelligent Systems and Applications (IJISA). Vol. 8. No. 12. Pp. 1-8. DOI: 10.5815/ijisa.2016.12.01 (in English).

2. Peleshko D., Rak T., Peleshko M., Izonin I. and Batyuk D. (2016). Two-frames image superresolution based on the aggregate divergence matrix. 2016 IEEE First International Conference on Data Stream Mining \& Processing (DSMP). Lviv, Ukraine. Pp. 235-238. DOI: 10.1109/DSMP.2016.7583548 (in English).

3. Pedersen M. and Hardeberg J. (2009). Survey of full-reference image quality metrics. Hogskolen i Gjoviks rapportserie 5, The Norwegian Color Research Laboratory (Gjovik University College). ISSN: 1890-520X (in English).

4. Norberg O., Westin P., Lindberg S., Klaman M., and Eidenvall L. (2001). A comparison of print quality between digital, offset and flexographic printing presses performed on different paper qualities. International Conference on Digital Production Printing and Industrial Applications. Pp. 380-385. IS\&Ts (in English).

5. Keelan B. W. (2002). Handbook of Image Quality: Characterization and Prediction. Marcel Dekker, New York (in English).

6. Halonen R., Nuutinen M., Asikainen R. and Oittinen P. (2010). Development and measurement of the goodness of test images for visual print quality evaluation. Image Quality and System Performance VII. Farnand S. P. and Gaykema F., eds., 7529, 752909-1-10. SPIE, San Jose, CA, USA (in English).

7. Chun-Ming Tsai and Hsi-Jian Lee. (2002). Binarization of color document images via luminance and saturation color features. IEEE Transactions on Image Processing. Vol. 11. No. 4. Pp. 434-451 (in English).

8. Pedersen M., Bonnier N., Hardeberg J. Y. and Albregtsen F. (2010). Attributes of image quality for color prints. Journal of Electronic Imaging 19. 011016-1-13 (in English).

9. CIE. Guidelines for the evaluation of gamut mapping algorithms. Tech. Rep. ISBN: 3-901906-26-6, CIE TC8-03 (156:2004) (in English).

10. Bonnier N., Schmitt F., Brettel H. and Berche S. (2006). Evaluation of spatial gamut mapping algorithms. Color Imaging Conference. 14. 56-61. IS\&T/SID (in English).

11. Cao G., Pedersen M. and Baranczuk Z. (2010). Saliency models as gamut-mapping artifact detectors. 5th European Conference on Colour in Graphics, Imaging, and Vision (CGIV), Joensuu, Finland. Pp. 437-443. IS\&T (in English).

12. Hardeberg J., Bando E. and Pedersen M. (2008). Evaluating colour image difference metrics for gamut-mapped images. Coloration Technology. 124. 243-253 (in English)

13. Lissner J., Preiss P., Urban M. S., Lichtenauer and Zolliker P. (2013). Image-Difference Prediction: From Grayscale to Color. IEEE Transactions on Image Processing. Vol. 22. No. 2. Pp. 435-446 (in English). 
14. Baranczuk Z., Zolliker P. and Giesen J. (2009). Image quality measures for evaluating gamut mapping. Color Imaging Conference. Albuquerque, NM, USA. Pp. 21-26. IS\&T/SID (in English).

15. Meng F., Li H., Liu G. and Ngan K. N. (2012). Object Co-Segmentation Based on Shortest Path Algorithm and Saliency Model. IEEE Transactions on Multimedia. Vol. 14. No. 5. Pp. 1429-1441 (in English).

doi: $10.32403 / 0554-4866-2018-2-76-46-56$

\section{ОПТИЧНА ЯКІСТЬ ЗОБРАЖЕННЯ ТА МЕТОДИ ЇЇ ВИЗНАЧЕННЯ}

Б. Гавриш ${ }^{1}$, О. Тимченко ${ }^{1,2}$, М. Логойда ${ }^{3}$, У. Партика ${ }^{4}$, М. Поліщук ${ }^{5}$, Ю. Слюсарчук ${ }^{3}$, О. Слюсарчук ${ }^{3}$

${ }^{1}$ Украӥнська академія друкарства, вул. Під Голоском, 19, Львів, 79020, Украӥна dana.havrysh@gmail.com

${ }^{2}$ Вармінсько-Мазурський Університет, вул. М. Очаповского, 2, Ольштин, 10-719, Польщуа o_tymch@ukr.net

${ }^{3}$ Національний університет «Львівська Політехніка», вул. С. Бандери, 12, Львів, 79013, Україна mykola.m.lohoida@lpnu.ua, Yuriy.M.Slyusarchuk@lpnu.ua,Olha.Z.Sliusarchuk@lpnu.ua

${ }^{4}$ Львівський інститут медсестринства та лабораторної медицини ім. Андрея Крупинського, вул. П. Дорошенка, 70, Львів, 79013, Україна ulanalemisko@gmail.com

5 Львівське вище професійне училище комп 'ютерних технологій та будівництва, вул. А. Лінкольна, 23, Львів, 79068, Украӥна marpoli1976@meta.ua

Основне завдання оцінки стану виробничих процесів - отримання об'єктивної інформащії про функціонування устаткування і виявлення резервів технологї для інтенсифікації виробництва, підвищзення його ефективності та якості, збільшення обсягів випуску продукиіi, зростання продуктивності праці, зниження усіх видів матеріальних і трудових витрат.

Всі оптичні прилади, незалежно від їх спещифіки і призначення, обов'язково мають одну загальну фізичну характеристику, яка називається «роздільна здат- 
ність». Дана фізична властивість є визначальною для всіх без винятку оптичних та оптико-вимірювальних приладів.

Межею роздільної здатності називається мінімальна відстань між сусідніми деталями (точками) об'єкта, при якій зображення деталей вже не сприймаються як окремі елементи об'єкту, а зливаються в одне изіле. Чим меншою є ия відстань, тим, відповідно, вищцюю є роздільна здатність приладу. Роздільна здатність будь-якого оптичного приладу оцінюється за його апаратними функиіями, щзо відображає всі фактори, які впливають на якість одержаного ичим приладом зображення. До таких чинників, безумовно, в першу чергу належать аберачія $i$ дифракція - дифрагування світловими хвилями перешкод $i$, як наслідок, відхилення їх від прямолінійного напряму.

Якість оптичного зображення - ступінь відповідності геометричній, фотометричній та спектральній характеристикам зображення і предмета. Зображення повинно бути подібне до предмету не тільки за контуром, але $і$ в кожній його точиі: через абераиї та дифракиії зображення одержується розмите, $i$ дрібна структура передається неправильно. Необхідно враховувати: при малому полі зору достатньо розглядати зображення за осьовою точкою, які повинні бути ідеальними; при художньому відтворенні дивляться відповідно за геометричними та спектральними характеристиками і необхідному коефічієнті передачі кольору; оптичні системи, щуо використовуються в каналі зв>язку, повинні передавати $і$ реєструвати максимальну кількість інформації, щзо надходить від об〉єкта.

3 урахуванням вимог загальної кваліметрії і показників властивостей, в статті відтворено дерево властивостей ичифрового відтворення поліграфічної продукиії у вигляді графічної схеми. До показників фотографічних властивостей, щзо характеризують відтворення деталей зображення, належать неоднорідність друку, градаційна точність і відтворення дрібних деталей. Неоднорідність друку зазвичай пов>язують з рівномірністю відтворення плашки (рівномірність друку) і наявністю сторонніх знаків, щзо в електрофотографічному прочесі друкування визначається за значенням оптичної густини фону (оптична густина фону). Градачійна точність визначається за характером передачі півтонів (градачія зображення) і рівню оптичної густини зображення.

Стаття надійшла до редакиії 19.07.2018. Received 19.07.2018. 